\title{
MULTI OBJECTIVE OPTIMIZATION OF TURNING OPERATION USING HYBRID DECISION MAKING ANALYSIS
}

\author{
Mehmet Alper SOFUOĞLU 1,*, R. Aykut ARAPOĞLU ${ }^{2}$, Sezan ORAK $^{1}$ \\ ${ }^{1}$ Mechanical Engineering Department, Engineering-Architecture Faculty, Eskişehir Osmangazi University, \\ Eskişehir, Turkey \\ ${ }^{2}$ Industrial Engineering Department, Engineering-Architecture Faculty, Eskişehir Osmangazi University, \\ Eskişehir, Turkey
}

\begin{abstract}
In this article, surface roughness, cutting forces and material removal rates of different materials are investigated in different cutting conditions in turning operations. First, vibration characteristics (natural and chatter frequency, stiffness coefficient and damping ratio) are determined by modal analysis and different cutting tests. Surface roughness, material removal rate and cutting forces were measured during experiments. By using these experiments, five different hybrid multi-criteria decision making models are proposed. Cutting parameters are optimized by maximizing material removal rate and minimizing surface roughness and cutting force.
\end{abstract}

Keywords: Best-Worst method, Cutting force; Multi criteria decision making, Multi objective optimization, Reference Ideal Method

\section{INTRODUCTION}

The modeling of cutting forces is one of the most researched topics in metal cutting theory. Cutting forces change according to some factors such as rigidity of machines, cutting depth, rake angle, cutting speed, feed rate, material of workpiece etc. Machined surface quality is another important criterion. The parameters used during machining of the material affect the accuracy of surface roughness [1-3].

In the literature, the optimization techniques on machining operations are traditional, statistical, heuristic etc.). In the past literature, geometric, dynamic and sequential quadratic programming [4-6] for the traditional methods; Taguchi [7] and experimental design [8] for the statistical methods and hill climbing algorithm [9], genetic algorithm [10-11], differential evolution algorithm [12], particle swarm algorithm [13-15] for the heuristic techniques were used.

Several studies investigating the effects of cutting parameters (cutting speed, feed rate, cutting depth, cutting tool geometry) on cutting forces and surface roughness have been carried out in past studies [1619]. Bartarya et al. [20] used uncoated cubic boron nitride (CBN) tools in the finishing operation of EN31 and developed a model to estimate cutting forces. Yen et al. [21] studied the effect of cutting tool insert on the cutting forces in orthogonal cutting conditions by using Finite Element Method. Benga and Abrao [22] analyzed the effect of cutting speed and feed rate on the surface roughness and tool life for the machining of $100 \mathrm{Cr} 6$ bearing steels. It is seen that the feed rate affects the surface roughness for ceramic and CBN cutting tools. Ozel et al. [23] examined the effect of cutting tool cutting edge geometry and cutting parameters on the surface roughness and cutting forces. They carried out hard turning experiments of AISI-H13 steel. Feng and Wang [24] used fractional factorial design to propose an empirical model for surface roughness. Chen [25] measured the cutting forces and surface roughness in the hardened steel machining process by using CBN cutting tools. Arsecularatne et al. [26] studied AISI D2 steel machining process by polycrystalline cubic boron nitride (PCBN) tools. Several techniques are

*Corresponding Author: asofuoglu@ogu.edu.tr 
tried to estimate surface roughness by using Artificial Neural Networks (ANN), Taguchi and regression models [27-29]. A number of studies were carried out in ANN modelling to estimate surface roughness. Generally, cutting speed, feed rate and depth of cut are considered. In other studies, material hardness is considered [30]. Kumar and Chauhan [31] published a paper in which they studied surface roughness of different $\mathrm{Al}$ composite materials in turning process. They demonstrated that the response surface methodology (RSM) produced successful results compared to ANN. Sahoo et al. [32] conducted an experimental study for AISI 1040 steel. RSM and ANN were used to estimate surface quality of workpiece. They reported that ANN is more appropriate than RSM. Moreover, compared to non-linear regression, ANN produced desirable results in several literature studies [33-34].

When investigating the studies in literature, it is reported that there is uncertainty in weighting of machining outputs. Also, it is seen that the used methods are rather complicated. In this research, BestWorst method (BWM) which has been recently introduced in the literature is proposed in the weighting process and the weights obtained from this model are implemented in five different decision making methods (Reference Ideal Model, Technique for Order Preference by Similarity to Ideal Solution (TOPSIS), Multi Criteria Optimization and Compromise Solution (VIKOR), Weighted sum approach (WSA) and multi-objective optimization on the basis of ratio analysis (MOORA)). Moreover, to the best of our knowledge, Reference Ideal Method (RIM) is used for the first time in machining problems.

In this article, surface roughness, cutting forces and material removal rates are examined in the turning processes of four different materials (AISI 4140, AISI 1040, Al-7075, Al-2024). A numerical study which aims to optimize these three machining outputs using five different hybrid multi-criteria decision making models is performed. This kind of hybrid models have not been studied before in the literature for machining problems.

\section{METHODOLOGY}

\subsection{Best-Worst Method (BWM)}

Best-Worst method is one of the newest methods used in the determination of weights in MCDM. The calculation is performed by using the steps below [35]:

Step 1: Determination of decision-making criteria $\left(\mathrm{c}_{1}, \mathrm{c}_{2} \ldots . . \mathrm{c}_{\mathrm{n}}\right)$.

Step 2: Determination of the best and the worst criteria

Step 3: Scoring of the best criterion versus the other criteria $a_{B}=\left(a_{B 1}, a_{B 2}, \ldots a_{B n}\right)$.

$a_{B j}$ : comparison scores of the best criterion $B$ with jth criterion.

Step 4: Scoring of the other criteria versus the worst criterion

$\mathrm{a}_{\mathrm{w}}=\left(\mathrm{a}_{1 \mathrm{w}}, \mathrm{a}_{2 \mathrm{w}} \ldots \mathrm{a}_{\mathrm{nw}}\right)^{\mathrm{T}}$.

$\mathrm{a}_{\mathrm{jw}}$ : The comparison scores of the worst criterion $\mathrm{w}$ with $\mathrm{jth}$ criterion.

Step 5: Calculation of optimum weights $\left(\mathrm{w}_{1}{ }^{*}, \mathrm{w}_{2}{ }^{*}, \mathrm{w}_{3}{ }^{*} \ldots \ldots \mathrm{w}_{\mathrm{n}}{ }^{*}\right)$ and index for consistency ratio $\left(\epsilon^{*}\right)$

The developed model is given below (Eq.1-4).

Min $\epsilon$

subject to 
Sofuoğlu et al. / Anadolu Univ. J. of Sci. and Technology A-Appl. Sci. and Eng. 18 (3)- 2017

$$
\begin{array}{cc}
\left|\frac{w_{B}}{w_{j}}-a_{B j}\right| \leq \epsilon & \mathrm{j}=1, \ldots \mathrm{n} \\
\left|\frac{w_{j}}{w_{W}}-a_{j w}\right| \leq \epsilon & \mathrm{j}=1, \ldots \mathrm{n} \\
\sum_{j} w_{j}=1 & \\
w_{j} \geq 0 &
\end{array}
$$

The consistency index $(\mathrm{CI})$ is given in Table 1 and consistency ratio is computed via Eq.5.

$$
\text { Consistency ratio }=\frac{\epsilon^{*}}{\text { consistency index }}
$$

Table 1. Consistency index table

\begin{tabular}{c|ccccccccc}
$\mathrm{a}$ BW & 1 & 2 & 3 & 4 & 5 & 6 & 7 & 8 & 9 \\
\hline $\mathrm{CI}$ & 0 & 0.44 & 1 & 1.63 & 2.3 & 3 & 3.73 & 4.47 & 5.23
\end{tabular}

\subsection{MOORA Methods}

MOORA method was proposed by Willem Karel M. Brauers and Edmundas Kazimieras Zavadskas with their studies in 2006. Different MOORA methods are studied in the literature [36].

-MOORA- Rate Method

-MOORA- Reference Point Approach

-MOORA- Significance Coefficient

-MOORA- Full-Multiplication Form

-MULTI-MOORA

Multi MOORA combines Rate and Reference Point Methods with Full Multiplication Form. Detailed explanation about Multi MOORA is given in Ref. [37].

\subsection{Weighted Sum Approach (WSA)}

The Weighted Sum Approach is one of the best known MCDM methods in the decision making literature. If all criteria are assumed as benefit criteria, higher values show better results. $a_{\mathrm{ij}}$ shows the performance value of $a_{i}$ th alternative for jth criterion and $w_{j}$ define the weight of jth criterion. $m$ and $n$ define the number of alternatives and the number of criteria, respectively. Total importance point of $a_{i}$ th alternative is calculated via Eq. 6 [38]:

$$
a_{i}=\lambda \sum_{j=1}^{n} w_{j} a_{i j}+(1-\lambda) \prod_{j=1}^{n} a_{i j} w_{j}
$$

Weighted aggregated sum product assessment (WASPAS) method is transformed to weighted product model (WPM) and when $\lambda$ is 1 , it becomes WSA method.

\subsection{TOPSIS Algorithm}

TOPSIS algorithm was developed by Yoon and Hwang. The steps of TOPSIS algorithm are given below [39]:

Step 1: Determination of decision matrix

Step 2: Determination of standard decision matrix

Step 3: Determination of weighted decision matrix

Step 4: Determination of ideal-negative ideal solutions 
The highest value of weighted evaluating factors in the weighted decision-making matrix is selected (the lowest one is selected if the objective is minimization). The ideal solution set is created by using Eq.7. $v_{\mathrm{ij}}$ shows the elements of weighted decision matrix for ith alternative and jth criterion.

$$
\mathbf{A}^{*}=\left\{\left(\max _{\mathbf{i}} \mathbf{v}_{\mathbf{i j}} \mid \mathbf{j} \in \mathbf{J}\right),\left(\min _{\mathbf{i}} \mathbf{v}_{\mathbf{i j}} \mid \mathbf{j} \in \mathbf{J}^{\prime}\right)\right\}
$$

The negative ideal solution set is created by selecting the lowest weighted evaluating factors in the matrix (if the objective is minimization, the highest one is selected). The negative ideal solution set is calculated using Eq.8:

$$
\mathbf{A}^{-}=\left\{\left(\min _{\mathbf{i}} \mathbf{v}_{\mathbf{i j}} \mid \mathbf{j} \in \mathbf{J}\right),\left(\max _{\mathbf{i}} \mathbf{v}_{\mathbf{i j}} \mid \mathbf{j} \in \mathbf{J}^{\prime}\right)\right\}
$$

J shows maximized cluster and J' shows minimized cluster.

Step 5: Determination of distinction measure

The deviations of the values of evaluating factors for each decision-making point from the solution sets are calculated by using the Euclidean distance approach. These deviations are called as distinction measures. The calculation of ideal distinction measure $\left(\mathrm{s}_{\mathrm{i}}^{*}\right)$ is given in Eq. 9 and the negative ideal distinction measure $\left(\mathrm{s}_{\mathrm{i}}^{-}\right)$is calculated in Eq. 10.

$$
\begin{aligned}
& s_{i}^{*}=\sqrt{\sum_{j=1}^{n}\left(v_{i j}-v_{j}^{*}\right)^{2}} \\
& s_{i}^{-}=\sqrt{\sum_{j=1}^{n}\left(v_{i j}-v_{j}^{-}\right)^{2}}
\end{aligned}
$$

Step 6: Determination of proximity values relative to ideal solution

Ideal and negative ideal distinction measures are used to calculate the proximity values. This value is the rate of negative ideal distinction measure in the total distinction measure. The equation is given below (Eq.11).

$$
c_{i}^{*}=\frac{S_{i}^{-}}{S_{i}^{-}+S_{i}^{*}}
$$

\subsection{VIKOR}

VIKOR has been proposed for multi-criteria optimization of complex system. The steps of the method are given below [40]:

Step 1: Calculation of the best $f_{i}+$ and the worst $f_{i}^{-}$values from $f_{i j}$ alternative-criteria matrix values (Eq.12-13).

$$
\begin{aligned}
& f_{i}^{+}=\max f_{i j} \\
& f_{i}^{-}=\min f_{i j}
\end{aligned}
$$


$\mathrm{i}=1,2,3 \ldots \mathrm{n}$ (the number of criteria)

$\mathrm{j}=1,2,3 \ldots \mathrm{m}$ (the number of alternatives)

Step 2: Calculation of $s_{j}$ (average group value) and $r_{j}$ (worst group value) (Eq.14-15).

$$
\begin{gathered}
s_{j}=\sum_{i=1}^{n} \frac{w_{i}\left(f_{i}^{+}-f_{i j}\right)}{f_{i}^{+}-f_{i}^{-}} \\
r_{j}=\max \left[\frac{w_{i}\left(f_{i}^{+}-f_{i j}\right)}{f_{i}^{+}-f_{i}^{-}}\right]
\end{gathered}
$$

Where $\mathrm{w}_{\mathrm{i}}$ shows the weight of ith criterion.

Step 3: Calculation of $q_{j}$ value (max.group benefit) (Eq.16)

$$
q_{J}=\frac{v\left(s_{j}-s^{+}\right)}{\left(s^{-}-s^{+}\right)}+\frac{(1-v)\left(r_{j}-r^{+}\right)}{\left(r^{-}-r^{+}\right)}
$$

where,

$\mathrm{s}^{+}, \mathrm{s}^{-}$: minimum and maximum values of $\mathrm{s}_{\mathrm{j}}$ respectively.

$\mathrm{r}^{+}, \mathrm{r}^{-}$: minimum and maximum values of $\mathrm{r}_{\mathrm{j}}$ respectively.

v: weight ratio to obtain maximum group benefit strategy

Step 4: Ranking of $s j, r_{J}$ and $q_{J}$ values and determine appropriate alternatives.

\subsection{Reference Ideal Method (RIM)}

This method was introduced by Cables et al. [41]. The steps are given as follows:

Step 1. Normalization process: In this process, reference ideal interval is determined. This includes label sets and simple values that show the maximum importance or relevance. The distance to reference ideal interval is calculated by using the equation below (Eq.17)

$$
\boldsymbol{d}_{\text {min }}(\boldsymbol{x},[\mathbf{C}, \mathbf{D}])=\min (|x-C|,|x-D|)
$$

$\mathrm{X}$ is the valuation for a given approach and the interval

$[\mathbf{C}, \mathbf{D}]$ is the reference ideal. The following equation is used to perform the normalization step.

where,

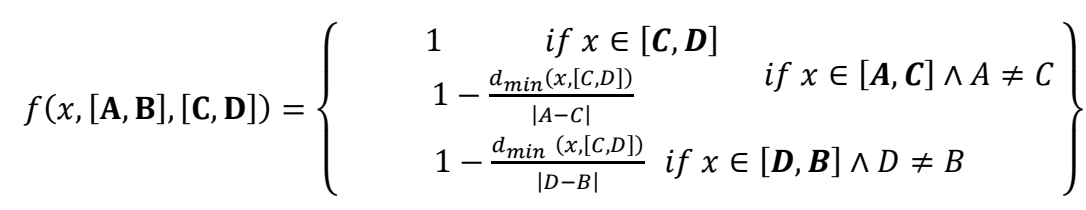

$[\mathbf{A}, \mathbf{B}]$ is the range that shows a universe of discourse.

[C,D] shows the Reference Ideal.

$x \in[\mathbf{A}, \mathbf{B}]$ and $[\mathbf{C}, \mathbf{D}] \subset[\mathbf{A}, \mathbf{B}]$ should be satisfied.

The function $\mathrm{f}$ allows to get a value that belongs to the unitary interval. 
Step 2. Compute the weighted normalized matrix $\mathbf{Y}$

Step 3. Compute the variation for each alternative $A_{i}$ (Eq.19-20).

$$
\begin{gathered}
I_{i}{ }^{+}=\sqrt{\sum_{j=1}^{n}\left(y_{i j}{ }^{\prime}-w_{j}\right)^{2}} \\
I_{i}{ }^{-}=\sqrt{\sum_{j=1}^{n}\left(y_{i j}{ }^{\prime}\right)^{2}}
\end{gathered}
$$

$\mathrm{i}=1,2,3 \ldots \mathrm{m}$ (the number of alternatives)

$\mathrm{j}=1,2,3 \ldots \mathrm{n}$ (the number of criteria)

where,

$\mathrm{y}_{\mathrm{ij}}$ :weighted normalized matrix values for the ith alternative and jth criterion

$w_{j}$ : the weight values for $\mathrm{jth}$ criterion

Step 4. Calculate the relative index ( $\left.\mathrm{r}_{\mathrm{i}}\right)$ (Eq.21)

$$
r_{i}=\frac{I_{i}^{-}}{I_{i}^{+}+I_{i}^{-}}
$$

Step 5. Rank the alternatives.

When the above methods given are compared, Best-Worst and Reference Ideal Methods are subjective methods compared to the other methods. Therefore, different scenarios can be created. The Best-Worst method is generally used to determine criteria weights. These criteria weights are then used by other methods.

\section{EXPERIMENTAL STUDY}

An experimental study is carried out using a manual turning lathe. The numbers of revolutions are between $355,500,710 \mathrm{rpm}$. The cross section of each cutting tool is $625 \mathrm{~mm}^{2}$. The cutting tool material is steel. The length of each workpiece is $300 \mathrm{~mm}$. The cutting tool length is $150 \mathrm{~mm}$. The insert materials are carbides coated with Kobalt, Tinalox Sn gold, Wc/Co-PVD-TiAlN AL2 plus. The workpiece diameters are 40 and $60 \mathrm{~mm}$. The cutting tool angles and the other parameters (tool overhang length, feed ratio, insert radius etc.) are given in Table 2. Materials used in the experiments and the composition of these materials are given in Table 3 [42].

Table 2. Cutting tool angles and the other parameters

\begin{tabular}{|c|c|c|c|}
\hline Tool angles & Value range $\left.\mathbf{(}^{\mathbf{9}}\right)$ & The other parameters & Value \\
\hline Approach angle & $93-100$ & Feed ratio $(\mathrm{mm} / \mathrm{rev})$. & 0.06 \\
\hline Back rake angle & $(-5)-0$ & Cutting speed (rpm) & $355,500,710$ \\
\hline End cutting angle & $35-45$ & Tool overhang length $(\mathrm{mm})$ & $80,90,100,110$ \\
\hline Side clearance angle & $(-7)-0$ & Radius of insert $(\mathrm{mm})$ & 0.8 \\
\hline Side rake angle & $(-7)-0$ & Workpiece length $(\mathrm{mm})$ & 300 \\
\hline
\end{tabular}


Table 3. Materials composition

\begin{tabular}{|c|c|c|c|c|c|c|c|c|c|c|c|c|c|}
\hline & Elements & Fe & Cr & Mn & C & Si & Mo & S & P & Al & Zn & Mg & Cu \\
\hline AISI & $\%$ & $\begin{array}{c}96.875- \\
4140\end{array}$ & $\begin{array}{c}0.8- \\
1.1\end{array}$ & $\begin{array}{c}0.75- \\
1\end{array}$ & $\begin{array}{c}0.38- \\
0.43\end{array}$ & $\begin{array}{c}0.15- \\
0.3\end{array}$ & $\begin{array}{c}0.15- \\
0.25\end{array}$ & 0.04 & 0.035 & - & - & - & - \\
\hline $\begin{array}{c}\text { AISI } \\
1040\end{array}$ & $\%$ & $98.9-99$ & - & $\begin{array}{c}0.6- \\
0.9\end{array}$ & $\begin{array}{c}0.37- \\
0.44\end{array}$ & - & - & $\leq 0.05$ & $\leq 0.04$ & - & - & - & - \\
\hline $\begin{array}{c}\text { Al- } \\
7075\end{array}$ & $\%$ & - & 0.23 & - & - & - & - & - & - & 90 & 5.6 & 2.5 & 1.6 \\
\hline $\begin{array}{c}\text { Al- } \\
2024\end{array}$ & $\%$ & - & - & 0.6 & - & - & - & - & - & 93.5 & - & 1.5 & 4.4 \\
\hline
\end{tabular}

The variables affecting surface roughness $\left(\mathrm{y}_{1}\right)$, cutting force $\left(\mathrm{y}_{2}\right)$ and material removal rate $\left(\mathrm{y}_{3}\right)$ are given in Table 4. In our study, tool overhang length $\left(\mathrm{x}_{1}\right)$, cutting depth $\left(\mathrm{x}_{2}\right)$, workpiece hardness $\left(\mathrm{x}_{3}\right)$ and cutting speed $\left(\mathrm{x}_{4}\right)$ are found to be more effective than the other independent variables. Therefore, only four independent variables are taken into consideration because variations in the other variables are negligible and their effect is low in our experimental study.

Table 4. Independent variables

\begin{tabular}{|c|}
\hline Overhang length of tool $(\mathrm{mm})$ \\
Tool stiffness coefficient $(\mathrm{N} / \mathrm{m})$ \\
Tool damping ratio $(\%)$ \\
Cutting depth (mm) \\
Approach angle $\left(^{0}\right)$ \\
End cutting angle $\left(^{0}\right)$ \\
Side clearance angle $\left(^{0}\right)$ \\
Side rake angle $\left({ }^{0}\right)$ \\
Back rake angle $\left({ }^{0}\right)$ \\
Hardness of workpiece $(\mathrm{HB})$ \\
Hardness of insert $(\mathrm{HB})$ \\
Cutting speed (rpm) \\
\hline
\end{tabular}

Cutting force values are measured when the chatter starts. KISTLER dynamometer is used during the measurement. DYNOWARE software is used to determine the cutting forces. The experimental setup for dynamometer is given in Figure 1.

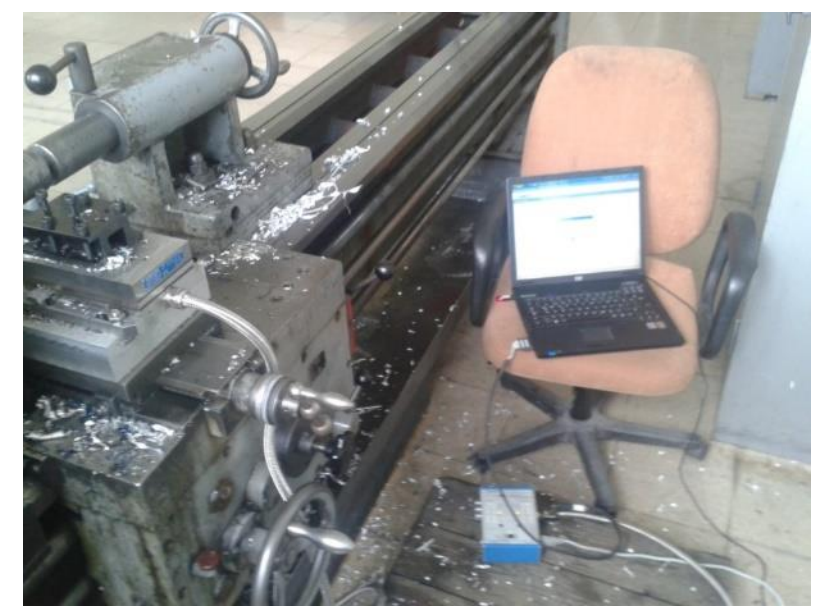

Figure 1. Dynamometer

Surface roughness values are measured at the start of chatter. A surface roughness instrument is used during the measurements. Experimental setup for surface roughness is given in Figure 2. Material removal rate is found by computing the weight difference of the workpiece before and after experiments. 


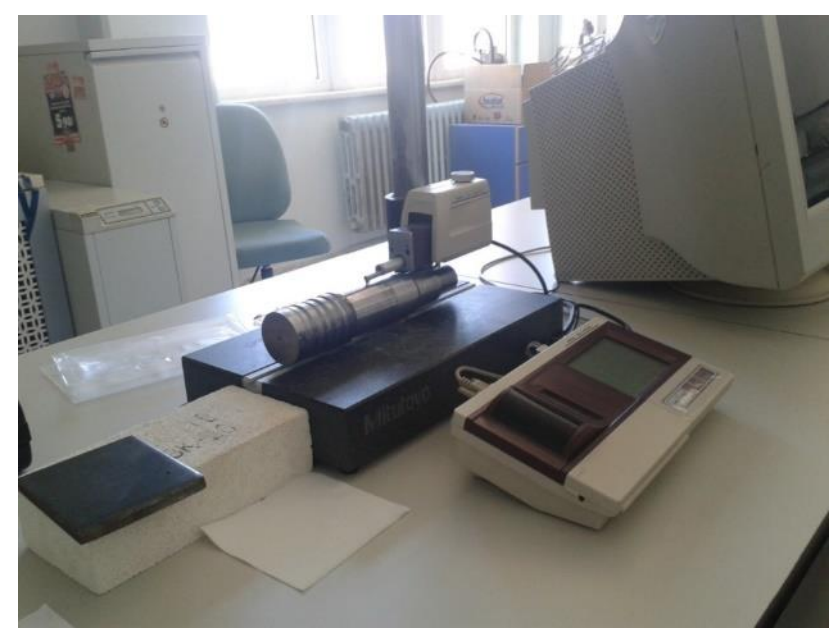

Figure 2. Surface roughness instrument

In the studies, the structural constants such as stiffness coefficient $(\mathrm{k})$, and structural damping ratio (s) of the cutting system are required to measure the rigidity and damping behavior of the system. The accelerometer is connected in the feed direction to perform hammer tests. Hammer test data are processed by using CUT PRO 8.0 software. The stable cutting depths are measured at different rpm values until chatter occurs. The chatter sound is recorded and analyzed by using a microphone and LABVIEW 7.1

\section{EXPERIMENTAL RESULTS}

\subsection{Vibration Characteristics and Surface Roughness}

The calculated vibration characteristics are given in Tables 5-6. Each experiment is repeated three times in the same cutting condition. The average surface roughness and stable cutting depth values are shown in Tables 7-8. It is obtained that when the cutting speed increases and the stable cutting depths decrease at the same overhang length, average surface roughness decreases as a result of increased cutting depths.

Table 5. Vibration characteristics of cutting tool during machining aluminum material

\begin{tabular}{|c|c|c|}
\hline $\begin{array}{c}\text { Tool overhang } \\
\text { length }(\mathbf{m m})\end{array}$ & $\begin{array}{c}\text { Natural frequency } \\
(\mathbf{H z})\end{array}$ & $\begin{array}{c}\text { Chatter } \\
\text { frequency }(\mathbf{H z})\end{array}$ \\
\hline $\mathbf{9 0}$ & 1550 & 1525 \\
\hline $\mathbf{1 0 0}$ & 937.1 & 1120 \\
\hline $\mathbf{1 1 0}$ & 853 & 1000 \\
\hline
\end{tabular}

Table 6. Vibration characteristics of cutting tool during machining steel material

\begin{tabular}{|c|c|c|}
\hline $\begin{array}{c}\text { Tool overhang } \\
\text { length } \\
\text { (mm) }\end{array}$ & $\begin{array}{c}\text { Natural Frequency } \\
\text { (Hz) }\end{array}$ & $\begin{array}{c}\text { Chatter } \\
\text { frequency } \\
\text { (Hz) }\end{array}$ \\
\hline $\mathbf{8 0}$ & 1308 & 1570 \\
\hline $\mathbf{9 0}$ & 942 & 1210 \\
\hline $\mathbf{1 0 0}$ & 794 & 800 \\
\hline $\mathbf{1 1 0}$ & 653.8 & 750 \\
\hline
\end{tabular}


Sofuoğlu et al. / Anadolu Univ. J. of Sci. and Technology A-Appl. Sci. and Eng. 18 (3)- 2017

Table 7. Average surface roughness $(\mathrm{Ra}-\mu \mathrm{m}) /$ stable cutting depths $(\mathrm{mm})$ values of Al-2024 alloy

\begin{tabular}{|c|c|c|c|}
\hline \multirow{2}{*}{$\begin{array}{c}\text { Tool overhang length } \\
(\mathbf{m m})\end{array}$} & \multicolumn{3}{|c|}{ Cutting speed (rpm) } \\
\cline { 2 - 4 } & $\mathbf{3 5 5}$ & $\mathbf{5 0 0}$ & $\mathbf{7 1 0}$ \\
\hline $\mathbf{9 0}$ & $8.48 / 13.20$ & $8.41 / 12.50$ & $8.02 / 12.00$ \\
\hline $\mathbf{1 0 0}$ & $4.78 / 10.00$ & $3.35 / 9.50$ & $2.34 / 9.00$ \\
\hline $\mathbf{1 1 0}$ & $4.12 / 7.90$ & $3.01 / 7.40$ & $2.13 / 7.00$ \\
\hline
\end{tabular}

Table 8. Average surface roughness $(\mathrm{Ra}-\mu \mathrm{m}) /$ stable cutting depths $(\mathrm{mm})$ values of steel and aluminum alloy

\begin{tabular}{|c|c|c|c|c|}
\hline \multirow{2}{*}{$\begin{array}{l}\text { Tool overhang } \\
\text { length }(\mathrm{mm})\end{array}$} & \multirow[t]{2}{*}{ Materials } & \multicolumn{3}{|c|}{ Cutting speed (rpm) } \\
\hline & & \multicolumn{3}{|c|}{710} \\
\hline 80 & AISI 1040 & \multicolumn{3}{|c|}{$3.80 / 4.00$} \\
\hline 80 & AISI 4140 & \multicolumn{3}{|c|}{$2.61 / 3.00$} \\
\hline & & 355 & 500 & 710 \\
\hline 90 & Al-7075 & $5.59 / 9.00$ & $4.87 / 8.50$ & $4.10 / 8.00$ \\
\hline 90 & AISI 1040 & $3.64 / 5.10$ & $3.60 / 4.40$ & $3.44 / 3.80$ \\
\hline 90 & AISI 4140 & $2.08 / 3.70$ & $2.07 / 3.20$ & $1.97 / 2.60$ \\
\hline
\end{tabular}

\subsection{Cutting Forces}

The values of cutting forces are obtained at predetermined stable cutting depths. The measurements are taken from $\mathrm{x}, \mathrm{y}, \mathrm{z}$ axes. After the measurements, the average resultant force is calculated using the forces obtained in the three axes. Average resultant cutting force values $(\mathrm{N})$ for steel and aluminum alloys are given in Tables 9-10. It is seen that cutting forces decrease when the cutting speed increases and the cutting depths decrease at the same tool overhang length

Table 9. Average resultant cutting force of Al-2024 (N)

\begin{tabular}{|c|c|c|c|}
\hline \multirow{2}{*}{$\begin{array}{c}\text { Tool overhang length } \\
(\mathbf{m m})\end{array}$} & \multicolumn{3}{|c|}{ Cutting speed (rpm) } \\
\cline { 2 - 4 } & $\mathbf{3 5 5}$ & $\mathbf{5 0 0}$ & $\mathbf{7 1 0}$ \\
\hline $\mathbf{9 0}$ & 670.80 & 650.00 & 548.80 \\
\hline $\mathbf{1 0 0}$ & 838.15 & 743.40 & 427.20 \\
\hline $\mathbf{1 1 0}$ & 700.10 & 600.30 & 436.00 \\
\hline
\end{tabular}

Table 10. Average resultant cutting force of steel and aluminum alloy $(\mathrm{N})$

\begin{tabular}{|c|c|c|c|c|}
\hline \multirow{2}{*}{$\begin{array}{l}\text { Tool overhang } \\
\text { length }(\mathrm{mm})\end{array}$} & \multirow[t]{2}{*}{ Materials } & \multicolumn{3}{|c|}{ Cutting speed (rpm) } \\
\hline & & \multicolumn{3}{|c|}{710} \\
\hline 80 & AISI 1040 & \multicolumn{3}{|c|}{286.14} \\
\hline 80 & AISI 4140 & \multicolumn{3}{|c|}{449.33} \\
\hline & & 355 & 500 & 710 \\
\hline 90 & $\mathrm{Al}-7075$ & 474.30 & 423.79 & 412.30 \\
\hline 90 & AISI 1040 & 500.20 & 400.30 & 343.69 \\
\hline 90 & AISI 4140 & 400.80 & 300.10 & 236.00 \\
\hline
\end{tabular}

The cutting forces in $90 \mathrm{~mm}$ tool overhang length and $500 \mathrm{rpm}$ for Al-2024 are shown in DYNOWARE program in Figure 3. The force in $\mathrm{Z}$ direction is more predominated than the forces in $\mathrm{X}$ and $\mathrm{Y}$ directions. Moreover, it is observed that the forces are not stable due to the start of chatter vibration. 


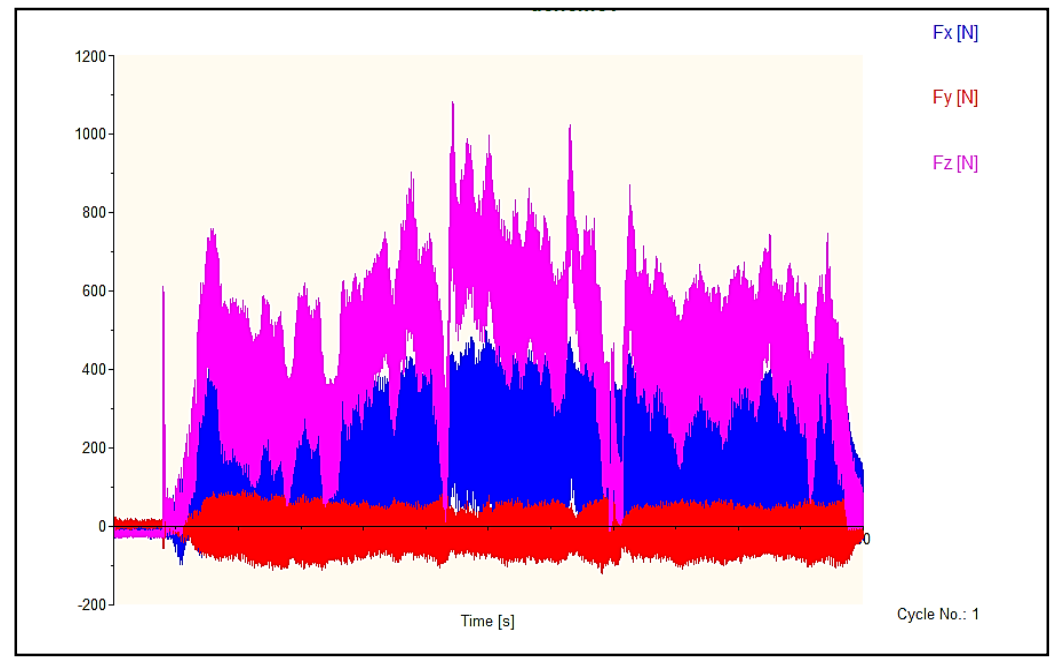

Figure 3. Cutting forces in $\mathrm{X}-\mathrm{Y}-\mathrm{Z}$ direction for $\mathrm{Al}-2024$ with $\mathrm{L}=90 \mathrm{~mm}$ and $500 \mathrm{rpm}$

All the results of the experiments are shown in Table A.1. in Appendix.

\section{NUMERICAL RESULTS}

In this stage, criteria are weighted using the Best-Worst method. The criteria points are evaluated by three experts who have experience in this area (Step 3-4). Rough machining conditions are taken into consideration. Material removal rate is selected as the best criterion, whereas surface roughness is chosen as the worst criterion. Criteria points are given in Table 11. According to determined criteria points, relative weights are calculated then average relative weights (ARW) of material removal rate, cutting force and surface roughness are found to be $66 \%, 25.67 \%$ and $8.33 \%$, respectively using Eq.1-5 (Table 11). Consistency ratios for each expert are less than 0.1 so it can be said that the relative weights are consistent. The purpose of the MCDM is to maximize the material removal rate (MRR) and to minimize the surface roughness and cutting force.

Table 11. The relative weights according to three experts

\begin{tabular}{|c|c|c|c|c|c|}
\hline Experts & MRR & $\begin{array}{c}\text { Cutting } \\
\text { force }\end{array}$ & Surface roughness & Consistency ratio & $\begin{array}{c}\text { Criteria points } \\
(\mathbf{a} 31, \mathbf{a} 2, \mathbf{a} 21)\end{array}$ \\
\hline 1 & 0.64 & 0.28 & 0.08 & 0.07 & $(8,3,2)$ \\
\hline 2 & 0.56 & 0.37 & 0.07 & 0.10 & $(8,8,3)$ \\
\hline 3 & 0.78 & 0.12 & 0.10 & 0.05 & $(8,6,1)$ \\
\hline ARW & 0.66 & 0.2567 & 0.0833 & & \\
\hline
\end{tabular}

\subsection{Best-Worst Method with Other MCDM Methods (Scenario-1)}

The obtained relative weights are used in different MCDM methods (MultiMOORA, TOPSIS, VIKOR, WSA and RIM. The parameters of the models are given below:

1. In RIM, reference ideal and range ideal are determined which are given below.

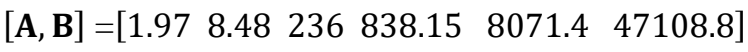
[C, D] $=\left[\begin{array}{llllll}1.97 & 1.97 & 236 & 236 & 47108.8 & 47108.8\end{array}\right]$

The upper and lower values of range ideal matrix are taken according to the lower and upper values of experimental values. The purpose of the model is to obtain minimum.surface roughness $(1.97 \mu \mathrm{m})$, 
minimum cutting force $(236 \mathrm{~N})$, and minimum material removal rate $\left(47108.8 \mathrm{~mm}^{3} / \mathrm{min}\right)$.

2. Two different normalization methods are used, vector and linear normalization in TOPSIS model.

3. In VIKOR model, $\mathrm{v}$ is taken as 0.5 .

4. Lambda $(\lambda)$ is chosen as 0.5 in WSA.

The rankings are given in Table 12. Rankings are given according to experiment number. For example, the ranking number of experiment\#1 is 13 and the ranking number of experiment\#20 is 5. According to results in Table 12, the best results are observed at the experiment \#11, whereas experiment \#15 produced the worst results. It is obtained that the rankings are nearly same for each model indicating that the results are consistent. The reason of the negligible differences is about the different mathematical representation of MCDM methods. In order to observe the correlation of rankings, Spearman ranking correlation test is used. In Table A.2., correlation coefficients (r) are higher than 0.95 and significance levels are lower than 5\%. According to Spearman Correlation test, rankings are consistent at 5\% significance level (Table A.2.).

Table 12. The results of the models

\begin{tabular}{|c|c|}
\hline $\begin{array}{c}\text { Methods used with } \\
\text { BWM }\end{array}$ & Experimental Rankings \\
\hline MULTIMOORA & $13-17-15-10-3-11-8-4-7-2-1-18-12-$ \\
& $6-20-16-9-19-14-5$ \\
\hline TOPSIS VECTOR & $15-17-16-13-3-11-9-4-6-2-1-18-12-$ \\
& $8-20-14-7-19-10-5$ \\
\hline TOPSIS LINEAR & $16-17-15-10-3-13-9-4-6-2-1-19-12-$ \\
& $8-20-14-7-18-11-5$ \\
\hline VIKOR & $14-18-16-13-3-10-9-4-7-2-1-17-11-$ \\
& $6-20-15-8-19-12-5$ \\
\hline WASPAS & $15-17-14-10-3-11-8-4-7-2-1-18-12-$ \\
& $6-20-16-9-19-13-5$ \\
\hline RIM & $15-17-12-10-3-11-19-4-6-2-1-18-$ \\
& $13-7-20-16-8-19-14-5$ \\
\hline Sum & $14-17-15-10-3-11-9-4-6-2-1-18-12-$ \\
& $7-20-16-8-19-13-5$ \\
\hline Aggregate & $15-17-10-13-3-11-9-4-6-2-1-18-12-$ \\
& $8-20-16-7-19-14-5$ \\
\hline
\end{tabular}

\subsection{Best-Worst Method with RIM (Scenario-2)}

In this stage, a new reference ideal matrix is determined as a Scenario-2. In this scenario, a new reference ideal matrix is given below.

$$
\begin{aligned}
& {[A, B]=\left[\begin{array}{llllll}
1.97 & 8.48 & 236 & 838.15 & 8071.4 & 47108.8
\end{array}\right]} \\
& {[\text { C, D }]=\left[\begin{array}{llllll}
1.97 & 3 & 236 & 400 & 40000 & 47108.8
\end{array}\right]}
\end{aligned}
$$

The upper and lower values of range ideal matrix are taken according to the lower and upper values of experimental values. The purpose of the model is to obtain surface roughness between $1.97-3 \mu \mathrm{m}$, cutting force between $236-400 \mathrm{~N}$, and material removal rate between $40000-47108.8 \mathrm{~mm}^{3} / \mathrm{min}$.

The results of the model (Best Worst-RIM) is given in Table 13. The best results are observed at the experiment \#11, whereas experiment \#18 produced the worst results. According to Spearman Correlation test, rankings are consistent with the other 5 models at 5\% significance level (Table A.2.). 
Table 13. The results of BWM with RIM (Scenario-2)

\begin{tabular}{|c|c|}
\hline Method used with BWM & Rankings \\
\hline RIM (Scenario-2) & $13-17-16-14-3-10-9-4-6-2-1-$ \\
& $18-11-7-19-15-8-20-12-5$ \\
\hline
\end{tabular}

In experiment \#11, the number of revolution is $710 \mathrm{rpm}$, cutting depth is $8 \mathrm{~mm}$. and tool overhang is 90 $\mathrm{mm}$. which are optimal conditions. In this condition, material is Al-7075 and its hardness is low compared to the other materials.

\section{CONCLUSION}

In this article, cutting force, surface roughness and material removal rate are determined for four different materials (AISI 4140, AISI-1040, Al-7075, Al-2024). Using experiments, five different hybrid multicriteria decision making models are used and these three machining outputs are optimized. Experiment \#11 produced the best result for each model, whereas experiment \#15 and \#18 are the worst. In future studies, these models may be applied to different machining operations such as milling, drilling etc.

\section{ACKNOWLEDGEMENT}

This study was supported by the Scientific and Technological Research Council of Turkey (TUBITAK) via 2228-B program and project number 115M123.

\section{APPENDIX}

Table A.1. The results of experiments

\begin{tabular}{|c|c|c|c|c|c|c|c|}
\hline $\begin{array}{l}\text { Experiment } \\
\text { no }\end{array}$ & $\begin{array}{c}\text { Tool } \\
\text { overhang } \\
\text { length }\left(\mathbf{x}_{1}\right) \\
(\mathbf{m m})\end{array}$ & $\begin{array}{c}\text { Cutting } \\
\text { depth }\left(\mathbf{x}_{2}\right) \\
(\mathbf{m m})\end{array}$ & $\begin{array}{l}\text { Workpiece } \\
\text { hardness } \\
\left(\mathbf{x}_{3}\right)(\mathrm{HB})\end{array}$ & $\begin{array}{c}\text { Cutting } \\
\text { speed }\left(\mathbf{x}_{\mathbf{4}}\right) \\
(\mathbf{r p m})\end{array}$ & $\begin{array}{c}\text { Surface } \\
\text { roughness }\left(\mathbf{y}_{1}\right) \\
\text { (Ra-micron) }\end{array}$ & $\begin{array}{c}\text { Average resultant } \\
\text { cutting force }\left(\mathrm{y}_{2}\right)(\mathbf{N}) \\
\left(\sqrt{\left(F x^{2}+F y^{2}+F z^{2}\right.}\right)\end{array}$ & $\begin{array}{l}\text { Material removal } \\
\text { rate }\left(\mathbf{y}_{3}\right)\left(\mathrm{mm}^{3} / \mathrm{min}\right)\end{array}$ \\
\hline 1 & 80 & 3.0 & 197 & 710 & 2.61 & 449.33 & 13650.8 \\
\hline 2 & 90 & 3.7 & 197 & 355 & 2.08 & 400.8 & 8071.4 \\
\hline 3 & 90 & 3.2 & 197 & 500 & 2.07 & 300.1 & 10133.5 \\
\hline 4 & 90 & 2.6 & 197 & 719 & 1.97 & 236 & 12109.1 \\
\hline 5 & 80 & 4.0 & 201 & 710 & 3.8 & 286.14 & 27837.0 \\
\hline 6 & 90 & 5.1 & 201 & 355 & 3.64 & 500.2 & 16995.3 \\
\hline 7 & 90 & 4.4 & 201 & 500 & 3.6 & 400.3 & 21232.1 \\
\hline 8 & 90 & 3.8 & 201 & 710 & 3.44 & 343.69 & 26648.6 \\
\hline 9 & 90 & 9.0 & 150 & 355 & 5.59 & 474.34 & 25294.2 \\
\hline 10 & 90 & 8.5 & 150 & 500 & 4.87 & 423.79 & 34447.6 \\
\hline 11 & 90 & 8.0 & 150 & 710 & 4.1 & 412.31 & 47108.8 \\
\hline 12 & 110 & 7.9 & 120 & 355 & 4.12 & 700.1 & 12793.0 \\
\hline 13 & 110 & 7.4 & 120 & 500 & 3.01 & 600.3 & 17575.3 \\
\hline 14 & 110 & 7.0 & 120 & 710 & 2.13 & 436 & 24357.4 \\
\hline 15 & 90 & 13.2 & 120 & 355 & 8.48 & 670.8 & 12012.7 \\
\hline 16 & 90 & 12.5 & 120 & 500 & 8.41 & 650 & 17671.4 \\
\hline 17 & 90 & 12.0 & 120 & 710 & 8.02 & $\begin{array}{l}548.8 \\
\end{array}$ & 25695.7 \\
\hline 18 & 100 & 10.0 & 120 & 355 & 4.78 & 838.15 & 13383.2 \\
\hline 19 & 100 & 9.5 & 120 & 500 & 3.35 & 743.4 & 18802.4 \\
\hline 20 & 100 & 9.0 & 120 & 710 & 2.34 & 427.2 & 26498.7 \\
\hline
\end{tabular}


Sofuoğlu et al. / Anadolu Univ. J. of Sci. and Technology A-Appl. Sci. and Eng. 18 (3) - 2017

Table A.2. Spearman correlation test (significance 2 tailed)

\begin{tabular}{|c|c|c|c|c|c|c|c|c|}
\hline \multicolumn{2}{|c|}{ Spearman's rho } & \multirow{2}{*}{$\begin{array}{c}\text { MOORA } \\
1.000\end{array}$} & \multirow{2}{*}{$\begin{array}{c}\text { TOPSIS } \\
\text { VECTOR } \\
.967(* *)\end{array}$} & \multirow{2}{*}{$\begin{array}{c}\begin{array}{c}\text { TOPSIS } \\
\text { LINEAR }\end{array} \\
.971(* *)\end{array}$} & \multirow{2}{*}{$\begin{array}{c}\text { VIKOR } \\
.983(* *)\end{array}$} & \multirow{2}{*}{$\frac{\text { WASPAS }}{.995(* *)}$} & \multirow{2}{*}{$\begin{array}{c}\text { RIM-1 } \\
.986(* *)\end{array}$} & \multirow{2}{*}{$\begin{array}{c}\text { RIM } \\
\text { (Sc.-2) }\end{array}$} \\
\hline MOORA & $\begin{array}{l}\text { Correlation } \\
\text { Coefficient }\end{array}$ & & & & & & & \\
\hline & Significance & . & .000 & .000 & .000 & .000 & .000 & .000 \\
\hline & $\mathrm{N}$ & 20 & 20 & 20 & 20 & 20 & 20 & 20 \\
\hline \multirow[t]{3}{*}{$\begin{array}{c}\text { TOPSIS } \\
\text { VECTOR }\end{array}$} & $\begin{array}{l}\text { Correlation } \\
\text { Coefficient }\end{array}$ & $.967(* *)$ & 1.000 & $.986(* *)$ & $.988(* *)$ & $.973(* *)$ & $.964(* *)$ & $.988(* *)$ \\
\hline & Significance & .000 & . & .000 & .000 & .000 & .000 & .000 \\
\hline & $\mathrm{N}$ & 20 & 20 & 20 & 20 & 20 & 20 & 20 \\
\hline \multirow[t]{3}{*}{$\begin{array}{c}\text { TOPSIS } \\
\text { LINEAR }\end{array}$} & $\begin{array}{l}\text { Correlation } \\
\text { Coefficient }\end{array}$ & $.971(* *)$ & $.986(* *)$ & 1.000 & $.971(* *)$ & $.980(* *)$ & $.976(* *)$ & $.965(* *)$ \\
\hline & Significance & .000 & .000 & . & .000 & .000 & .000 & .000 \\
\hline & $\mathrm{N}$ & 20 & 20 & 20 & 20 & 20 & 20 & 20 \\
\hline \multirow[t]{3}{*}{ VIKOR } & $\begin{array}{l}\text { Correlation } \\
\text { Coefficient }\end{array}$ & $.983(* *)$ & $.988(* *)$ & $.971(* *)$ & 1.000 & $.983(* *)$ & $.970(* *)$ & $.994(* *)$ \\
\hline & Significance & .000 & .000 & .000 & . & .000 & .000 & .000 \\
\hline & $\mathrm{N}$ & 20 & 20 & 20 & 20 & 20 & 20 & 20 \\
\hline \multirow[t]{3}{*}{ WASPAS } & $\begin{array}{l}\text { Correlation } \\
\text { Coefficient }\end{array}$ & $.995(* *)$ & $.973(* *)$ & $.980(* *)$ & $.983(* *)$ & 1.000 & $.992(* *)$ & $.974(* *)$ \\
\hline & Significance & .000 & .000 & .000 & .000 & . & .000 & .000 \\
\hline & $\mathrm{N}$ & 20 & 20 & 20 & 20 & 20 & 20 & 20 \\
\hline \multirow[t]{3}{*}{ RIM-1 } & $\begin{array}{l}\text { Correlation } \\
\text { Coefficient } \\
\end{array}$ & $.986(* *)$ & $.964(* *)$ & $.976(* *)$ & $.970(* *)$ & $.992(* *)$ & 1.000 & $.964(* *)$ \\
\hline & Significance & .000 & .000 & .000 & .000 & .000 & . & .000 \\
\hline & $\mathrm{N}$ & 20 & 20 & 20 & 20 & 20 & 20 & 20 \\
\hline \multirow[t]{3}{*}{$\begin{array}{c}\text { RIM } \\
\text { (Sc.-2) } \\
\end{array}$} & $\begin{array}{l}\text { Correlation } \\
\text { Coefficient } \\
\end{array}$ & $.977(* *)$ & $.988(* *)$ & $.965(* *)$ & $.994(* *)$ & $.974(* *)$ & $.964(* *)$ & 1.000 \\
\hline & Significance & .000 & .000 & .000 & .000 & .000 & .000 & . \\
\hline & $\mathrm{N}$ & 20 & 20 & 20 & 20 & 20 & 20 & 20 \\
\hline
\end{tabular}

\section{REFERENCES}

[1] Stout KJ. Engineering surfaces - A Philosophy of Manufacture (A Proposal For Good Manufacturing Practice), Proc. Instn.Mech.B, 1998; 212:169 - 174.

[2] Griffiths BJ. Manufacturing Surface Technology, In: Surface Integrity and Functional Performance, Penton Press, London, 2001.

[3] Puertas I and Luis Perez CJ. Surface Roughness Prediction By Factorial Design of Experiments in Turning Processes, Journal of Materials Processing Technology, 2003;143 - 144: 390 - 396.

[4] Jha NK. A discrete data base multiple objective optimization of milling operation through geometric programming. Journal of Engineering for Industry, 1990;112: 368-374.

[5] Wang ZG, Rahman M, Wong and Sun J,Optimization of multi-pass milling using parallel genetic algorithm and parallel genetic simulated annealing. International Journal of Machine Tools and Manufacture, 2005; 45(15):1726-1734.

[6] Maeda O, Cao Y and Altıntaş Y. Expert spindle design system. International Journal of Machine Tools and Manufacture, 2005; 45(4-5):537-548.

[7] Ghani JA, Choudhury I.A and Hassan HH, Application of Taguchi method in the optimization of end milling parameters. Journal of Materials Processing Technology, 2004; 145(1):84-92. 
[8] Vivancos J, Luis CJ, Costa L and Ortiz JA. Optimal machining parameters selection in high speed devir milling of hardened steels for injection moulds. Journal of Materials Processing Technology, 2004; 155-156:1505-1512.

[9] Budak E. An analytical design method for milling cutters with non-constant pitch to increase stability, Part 1: Theory and Part 2: Application. Journal of Manufacturing Science and Engineering, 2003;125: 29-38.

[10] Onwubolu G. Optimization of milling operations for the selection of cutting conditions using Tribes. Proceedings of the Institution of Mechanical Engineers, Part B: Journal of Engineering Manufacture, 2005;219(10):761-771.

[11] Stoic A, Kopac J and Cukor G. Testing of machinability of mould steel 40CrMnMo7 using genetic algorithm. Journal of Materials Processing Technology, 2005;164-165:1624-1630.

[12] Saikumar S and Shunmugan MS. Parameter selection based on surface finish in high speed finish in high speed end milling using differential evolution. Materials and Manufacturing Processes, 2008; 21(4):341-347.

[13] Tandon V, El-Mounayri $\mathrm{H}$ and Kishawy $\mathrm{H}$. NC end milling optimization using evolutionary computation. International Journal of Machine Tools and Manufacture, 2002;42(5):595-605.

[14] Kurdi MH, Schmitz TL, Haftka RT and Mann BP. Simultaneous optimization of material removal rate and part accuracy in high speed milling. ASME International Mechanical Engineering Congress and Exposition (IMECE), 2004:1001-1009.

[15] Baskar N, Asokan P, Prabhaharan G and Saravanan R. Optimization of machining parameters for milling operations using non-conventional methods. The International Journal of Advanced Manufacturing Technology, 2005; 25(11):1078-1088.

[16] Çelik YH, Kilickap E, Güney M. Investigation of cutting parameters affecting on tool wear and surface roughness in dry turning of Ti-6Al-4V using CVD and PVD coated tools, J Braz Soc Mech Sci Eng, 2016:1-9.

[17] Ferreira R, Řehoř J, Lauro CH, Carou D, Davim JP. Analysis of the hard turning of AISI H13 steel with ceramic tools based on tool geometry: surface roughness, tool wear and their relation, J Braz Soc Mech Sci Eng, 2016;38:2413-2420

[18] Madić M, Radovanović M. Modeling and analysis of correlations between cutting parameters and cutting force components in turning AISI 1043 steel using ANN, J Braz Soc Mech Sci Eng, 2013;35:111.

[19] Saglam H, Unsacar F and Yaldiz S. Investigation of the effect of rake angle and approaching angle on main cutting force and tool tip temperature, International Journal of Machine Tools and Manufacture, 2006; 46.2:132-141.

[20] Bartarya G and Choudhury SK. Effect of cutting parameters on cutting force and surface roughness during finish hard turning AISI52100 grade steel, Procedia CIRP, 2012;1:651-656.

[21] Yen YC, Jain A and Altan T. A finite element analysis of orthogonal machining using different tool edge geometries, Journal of Materials Processing Technology, 2004; 146.1:72-81. 
[22] Benga GC and Abrao AM. Turning of hardened 100Cr6 bearing steel with ceramic and PCBN cutting tools, Journal of Materials Processing Technology, 2003;143;237-241.

[23] Özel T, Hsu TK and Zeren E. Effects of cutting edge geometry, workpiece hardness, feed rate and cutting speed on surface roughness and forces in finish turning of hardened AISI H13 steel, The International Journal of Advanced Manufacturing Technology, 2005; 25.3-4:262-269.

[24] Wang X and Feng CX. Development of empirical models for surface roughness prediction in finish turning, The International Journal of Advanced Manufacturing Technology, 2002; 20.5:348-356.

[25] Chen W. Cutting forces and surface finish when machining medium hardness steel using CBN tools, International Journal of Machine Tools and Manufacture, 2000; 40.3:455-466.

[26] Arsecularatne JA, Zhang LC, Montross C, Mathew P. On machining of hardened AISI D2 steel with PCBN tools, Journal of Materials Processing Technology, 2006;171.2:244-252.

[27] Mahdavinejad RA, Khani N. Fakhrabadi MMS. Optimization of milling parameters using artificial neural network and artificial immune system, J Mech Sci Technol, 2012; 26:4097-4104.

[28] Davim JP. Design of optimisation of cutting parameters for turning metal matrix composites based on the orthogonal arrays, J Mater Process Technol 2003; 132:340-344.

[29] Al Hazza MHF, Adesta EYT, Hasan MH, Shaffiar N. Surface roughness modeling in high speed hard turning using regression analysis, Int Rev Mech Eng 2014; 8:431-436.

[30] Gaitonde VN, Karnik S, Figueira L, Davim JP. Performance comparison of conventional and wiper ceramic inserts in hard turning through artificial neural network modeling, Int J Adv Manuf Technol, s 2011;52:101-114.

[31] Kumar R, Chauhan S. Study on surface roughness measurement for turning of Al 7075/10/SiCp and $\mathrm{Al} 7075$ hybrid composites by using response surface methodology (RSM) and artificial neural networking (ANN), Measurement, 2015; 65:166-180.

[32] Sahoo A, Rout A, Das D. Response surface and artificial neural network prediction model and optimization for surface roughness in machining, Int J Ind Eng Comput, 2015; 6: 229-240.

[33] Acayaba GMA, Escalona PM. Prediction of surface roughness in low speed turning of AISI316 austenitic stainless steel, CIRP J Manuf Sci Technol, 2015; 11:62-67.

[34] Karabulut S. Optimization of surface roughness and cutting force during AA7039/Al2O3 metal matrix composites milling using neural networks and Taguchi method, Measurement, 2015;66:139149.

[35] Rezaei J. Best-worst multi-criteria decision-making method, Omega, 2015; 53:49-57.

[36] Brauers WK, Zavadskas EK. The Moora method and its application to privatization in a Transition economy, Control and Cybernetics, Systems Research of the Polish Academy of Sciences, ISSN:0324-8569, 2006; 35-2: 445-469.

[37] Brauers WKM, Zavadskas EK. Project management by MULTIMOORA as an instrument for transition economies. Technological and Economic Development of Economy, 2010; 16(1):5-24.

[38] Nedjah N, Mourelle LM. Real-world Multi-objective System Engineering. Nova Publishers, 2005. 
Sofuoğlu et al. / Anadolu Univ. J. of Sci. and Technology A-Appl. Sci. and Eng. 18 (3) - 2017

[39] Tzeng GH, Huang JJ. Multiple Attribute Decision Making: Methods and Applications. CRC Press, 2011.

[40] Opricovic S, Tzeng GH. Compromise solution by MCDM methods: A comparative analysis of VIKOR and TOPSIS. European Journal of Operational Research, 2004; 156(2):445-455

[41] Cables E, Lamata MT, Verdegay JL. RIM-reference ideal method in multicriteria decision making. Information Science, 2016; 337-338:1-10.

[42] www.matweb.com 